Dirk Younker MD, Randall Clark MD, Joy Tessem mD, Thomas H. Joyce III MD, Martha Kubicek RN

\title{
Bupivicaine-fentanyl epidural analgesia for a parturient in status asthmaticus
}

Regional anaesthesia is a suitable technique for the maragement of the asthmatic parturient. We report the case of an asthmatic gravida in labour in whom prompt institution of bupivicaine-fentanyl epidural analgesia was associared with enhancement of the effectiveness of concurrent medical therapy for bronchospasm. Prior to the initiation of epidural blockade, inhaled atropine was employed in an effort to reduce parasympatiteric tone in the bronchial smooth muscle. Sustained clinical improvement did not occur until after delivery of the fetus and placenta.

The reported incidence of asthma in pregnancy is approximately 1.0 per cent; these same reports reveal an incidence of status asthmaticus approaching 0.2 per cent. ${ }^{1.2}$ The majority of asthmatics appear to tolerate pregnancy and parturition with minimal exacerbation of their disease. However, it should be recognized that those patients who have a history of status asthmaticus when not pregnant, as well as those asthmatics whose symptoms have worsened during earlier pregnancies, represent a category of paticnts with a remarkably high incidence of maternal and fetal morbidity and mortality. ${ }^{1-4}$ Indeed, termination of pregnancy by emergency Caesarean section has been performed as a life-saving measure in moribund asthmatic mothers., 5

Regional anaesthesia has been described as the technique of choice for the management of the asthmatic parturient. ${ }^{7,8}$ We report the case of an asthmatic gravida in labour in whom prompt institution of bupivicaine-

\section{Key words}

ANAESTHESIA: obstetriC; ANAESTHETIC TECHNIQUES, REGIONAL: epidural, epidural narcotics; LUNG; asthma; ANALGESICS: fentanyl.

From the Department of Anesthesiology, Baylor College of Medicine, Houston, Texas.

Address correspondence to: Dr. Younker, Department of Anesthesiology, Baylor College of Madicine, One Baylor Plaza, Houston, Texas 77030 . fentanyl epidural analgesia enhanced the effectiveness of concurrent medical therapy for bronchospasm. Before the initiation of epidural blockade, inhalation therapy with aerosolized atropine was employed in an effort to reduce parasympathetic tone in the bronchial smooth muscle. Sustained clinical improvement did not occur until after delivery of the fetus and placenta.

\section{Case report}

A 34-year-old gravida 3, pard 2, in her 35th week of pregnancy was admitted to the labour suite following the onset of regular uterine contractions and the spontaneous rupture of the membranes. She was diaphoretic, had laboured respirations with audible wheezes and a cough productive of green, tenacious sputum. She was very agitated and would not lie supine.

Her past medical history revealed episodes of coughing and wheezing which regularly occurred during her menstrual periods and which abated without therapy. During her first two pregnancies she had been free of respiratory complaints. Early in the current pregnancy she had devcloped a persistent cough, wheezing and dyspnoea which had necessitated seven admissions for medical management because her symptoms could not be controlled on outpatient therapy. Her chronic medications were oral aminophylline, oral terbutaline and inhaled metoproterenol. During her eighth week of pregnancy, she had required a tapidly tapered course of oral corticostcroid therapy. Her theophylline levels (random) were consistently within the therapeutic range. During symptomfree periods, her forced vital capacity, one-minute forced expiratory volume and mid-expiratory flow rates were normal. She had no history of atopy.

Her vital signs at the time of admission were: axillary temperature $36.9^{\circ} \mathrm{C}$, heart rate 130 beats $\min ^{-1}$, respiratory rate 30 breaths $\cdot \mathrm{min}^{-1}$ and laboured, and blood pressure $150 / 74 \mathrm{mmHg}$. Auscultation of the chest revealed inspiratory and expiratory wheezes to be present diffusely over both lung fields. The remainder of the physical examination was unremarkable. Chest radiography revealed a right middle lobe infiltrate. Arterial blood gas analysis ( $\mathrm{FrO}_{2} 0.21$ ) showed: $\mathrm{PO}_{2} 77 \mathrm{mmHg}, \mathrm{PCO}_{2}$ 
$32 \mathrm{mmHg}, \mathrm{pH} 7.41$ and haemoglobin saturation 95 per cent. The serum electrolytes and haematocrit were normal for this stage of pregnancy. A serum theophylline determination was reported as $9.5 \mathrm{mg} \cdot \mathrm{dl}^{-1}$. The white blood cell count revealed 14,800 cells $\cdot \mathrm{mm}^{-3}$ and no eosinophils were noted on peripheral blood smear. The fetal heart rate was 146 beats $\cdot \mathrm{min}^{-1}$.

At this time, $6 \mathrm{~L} \cdot \mathrm{min}^{-1}$ of humidified supplemental $\mathrm{O}_{2}$ were administered by non-rebreathing face mask. Analysis of arterial blood gases at this time revealed: $\mathrm{PO}_{2} 243$ $\mathrm{mmHg}, \mathrm{PCO}_{2} 35 \mathrm{mmHg}, \mathrm{pH} 7.41$ and haemoglobin saturation 99 per cent. A Gram's stain of sputum revealed Gram-positive intracellular diplococci. The following drugs were then administered: terbutaline $0.25 \mathrm{mg} \mathrm{SC}$, aminophylline $250 \mathrm{mg}$ slowly IV, metoproterenol $0.3 \mathrm{ml}$ in $3.0 \mathrm{ml}$ sterile saline by jet nebulizer and piperacillin 4.0 gm slowly IV. At this time, an internal fetal monitor, an ECG and a left radial arterial line were placed. The fetal heart rate was 170 beats $\mathrm{min}^{-1}$.

Ninety minutes later, the patient complained that she was too tired to breathe. The fetal heart rate decreased to 100 beats $\min ^{-1}$. Analysis of arterial blood gas, with 10 $\mathrm{L} \cdot \mathrm{min}^{-1}$ humidified $\mathrm{O}_{2}$ delivered by a non-rebreathing mask showed: $\mathrm{PO}_{2} 78 \mathrm{mmHg}, \mathrm{PCO}_{2} 36 \mathrm{mmHg}$, $\mathrm{pH} 7.34$ and haemoglobin saturation 95 per cent. Metoprotereno] $0.3 \mathrm{ml}$ in $3.0 \mathrm{ml}$ sterile saline was administered by jet nebulizer and hydrocortisone hemisuccinate $1.0 \mathrm{~g}$ was given slowly IV. Preparations for emergency intubation and delivery of the fetus by Caesarean section were made. However, the patient reported a slight improvernent in her shortness of breath. A second arterial blood gas analysis showed: $\mathrm{PO}_{2} 140 \mathrm{mmHg}, \mathrm{PCO}_{2} 30 \mathrm{mmHg}, \mathrm{pH} 7.41$ and haemoglobin saturation 99 per cent. The fetal heart rate had increased to 140 beats min $^{-1}$.

Three hours later, the patient became diaphoretic, developed audible wheezes and complained of severe shortness of breath. Atropine $2.0 \mathrm{mg}$ in $3 \mathrm{ml}$ sterile saline was administered by jet nebulizer. Analysis of arterial blood gases following atropine administration and with the patient breathing 50 per cent humidified $\mathrm{O}_{2}$ delivered by a Venturi mask revealed: $\mathrm{PO}_{2} 104 \mathrm{mmHg}, \mathrm{PCO}_{2} 30$ $\mathrm{mmHg}, \mathrm{pH} 7.42$ and haemoglobin saturation 99 per cent. Following administration of the atropine, the matemal heart rate did not increase and the fetal heart rate ranged between $140-150$ beats min $^{-1}$. The patient was noted to be sleeping comfortably on her left side.

Two hours later, the decision was made to induce labour with pitocin. At this time, the patient was diaphoretic and complained of mild shortness of breath. Arterial blood gas analysis ( 50 per cent humidified $\mathrm{O}_{2}$ delivered by Venturi mask) revealed: $\mathrm{PO}_{2} 91 \mathrm{mmHg}$, $\mathrm{PCO}_{2} 27 \mathrm{mmHg}, \mathrm{pH} 7.49$ and haemoglobin saturation 96 per cent. It was thought to be beneficial for the patient to institute epidural analgesia for labour, prior to initiation of pitocin augmentation. Therefore, following a "preload" of $1000 \mathrm{ml}$ of crystalloid solution, analgesia to the tenth thoracic dermatome was obtained utilizing bupivicaine 0.5 per cent, $3.0 \mathrm{ml}$ with $15 \mu \mathrm{g}$ epinephrine as a test dose followed by a solution of bupivicaine 0.125 per cent 10.0 $\mathrm{ml}$ with fentanyl $5 \mu \mathrm{g} \cdot \mathrm{ml}^{-1}$ injected in divided doses through the epidural catheter. Maternal vital signs following institution of epidural blockade were: blood pressure $110 / 50 \mathrm{mmHg}$, heart rate 100 beats $\mathrm{min}^{-1}$ and respiratory rate 20 breaths min $^{-1}$ and unlaboured. Fetal heart rate ranged between $130-140$ beats $\cdot \mathrm{min}^{-1}$.

The patient slept quietly throughout an uneventful three-hour labour, requiring no further injections of the bupivicaine-fentanyl mixture for analgesia. At the end of labour, she delivered spontaneously a male jnfant with Apgar scores of nine at one and five minutes after birth. One hour after delivery, the patient had no wheezes on examination of the chest and analysis of arterial blood gases (with supplemental humidified $\mathrm{O}_{2} 3 \mathrm{~L} \cdot \mathrm{min}^{-1}$ delivered by nasal cannulae) revealed: $\mathrm{PO}_{2} 179 \mathrm{mmHg}$, $\mathrm{PCO}_{2} 22 \mathrm{mmHg}, \mathrm{pH} 7.47$ and haemoglobin saturation 99 per cent.

\section{Discussion}

Several reviews outline the pathophysiology and pharmacotherapy of acute and chronic asthma. ${ }^{7,9-11}$ From these studies, guidelines emerge which aid the obstetric anaesthetist in managing the parturient in status asthmaticus.

The matemal arterial carbon dioxide tension during the third trimester of pregnancy tanges between $28 \mathrm{mmHg}-$ $31 \mathrm{mmHg}^{12,13}$ The normal maternal alkalaemia of pregnancy and a painful labour easily may be worsened by the hyperventilation present in the early stages of an acute asthmatic attack. If the arterial oxygen tension of a pregnant asthmatic is reduced in this alkalotic milieu, it is logical to assume that fetal oxygenation will be rapidly and severely compromised. ${ }^{14.15}$ Therefore, it is essential to avoid maternal arterial hypoxaemia through the use of supplemental hurnidified oxygen therapy. ${ }^{16-19}$ Adequale hydration, treatment of any concurrent maternal pulmonary infection and chest physiotherapy for mobilization of secretions are necessary secondary measures designed to maintain or enhance oxygen exchange

A decreasing maternal arterial $\mathrm{PO}_{2}$ in the presence of a maternal arterial $\mathrm{PCO}_{2}>35 \mathrm{mmHg}$ and a $\mathrm{pH}<7.35$ indicates respiratory failure in the pregnant asthmatic. ${ }^{2} \mathrm{At}$ this point, intubation and assisted mechanical ventilation should be considered, while every effort is made to optimize medical therapy. Because the insertion of an endotracheal tube into an unanaesthetized trachea is a potent stimulus for bronchospasm, intubation itself should 
be considered a temporizing measure until the status asthmaticus is controlled through other means. Had the patient described above not responded to the medical regimen developed for her, immediate orotracheal intubation and expeditious delivery of the fetus and placenta were planned.

The addition of inhaled atropine to a regimen of metoproterenol, corticosteroids and aminophylline was suggested by evidence which indicates its efficacy in those nonpregnant asthmatics in whom bronchial hyperreactivity to cholinergic stimuli elicits bronchospasm. ${ }^{20-24}$ Unfortunately, there are limited published data concerning the effects of inhaled anticholinergics on the course of labour or on the fetoplacental unit. Hernandez et al. ${ }^{5}$ describe a case in which inhaled atropine was successfully used to alleviate the symptoms of a pregnant asthmatic; no specific mention is made of adverse side effects. Its use in our patient, who was under continuous monitoring with an electrocardiogram, intra-arterial line and extemal tocodynamometer, appeared to result in subjective symptomatic improvement without associated maternal or fetal tachycardia or signs of fetal distress.

In our patient, the judicious institution of epidural analgesia prior to pitocin augmentation of labour appeared to provide an additional beneficial effect on the resolution of her status asthmaticus. Effective pain relief will allay maternal anxiety, which of itself may provoke an attack of asthma. ${ }^{3}$ Such relief may also reduce the tremendous involuntary increase in maternal minute ventilation which occurs during a painful labour. ${ }^{11}$ Uncontrolled hyperventilation will worsen the respiratory alkalosis usually present in the early stages of status asthmaticus with resultant detrimental effects on fetal oxygenation. In the patient presented above, epidural analgesia was carefully instituted before labour was induced with pitocin. Fentanyl was added to the local anaesthetic mixture in an effor to increase the maternal analgesia and to minimize the total dose of bupivicaine. ${ }^{25-27}$

In a patient such as this, it is essential to avoid a respiratory arrest resulting from a high epidural blockade or from a total spinal block following unintentional dural puncture. Therefore, close attention should be given to the technique of induction of epidural analgesia, raising the level of blockade slowly and utilizing divided doses of anaesthetic injected after careful tests of aspiration. The depressant effects of narcotics on the central ventilatory response to carbon dioxide must also be kept in mind. The lowest possible concentration of epidural fentanyl should be employed and naloxone should be available for immediate administration if signs of narcotic-induced respiratory depression become apparent.

In summary, status asthmaticus in the parturient carries a high risk of maternal and fetal morbidity and mortality.
Production of fetal asphyxia through maternal arterial hypoxaemia and respiratory alkalosis must be avoided, utilizing if necessary controlled mechanical ventilation. The addition of aerosolized atropine to a medical regimen consisting of methylxanthines, corticosteroids and inhaled beta-sympathomimetic agents may decrease cholinergic tone in the matemal bronchial smooth muscle and appears to have little effect on the fetus. Properly instituted epidural analgesia may also alleviate bronchospasm brought on by the maternal response to a painful labour. In the absence of intravenous or subarachnoid injection, fentanyl added to the epidural local anaesthetic mixture appears to produce profound analgesia with minimal effect on maternal respiratory effort or fetal well-being.

\section{References}

1 Gordon $M$, Niswander $K R$. Berendes $H$, Kantor $A G$. Fetal morbidity following potentially anoxigenic conditions. VII. Bronchial asthma. Am J Obstet Gynocol 1970; 106: 421-9.

2 Hernandez E, Angell CS, Johnson JWC. Asthma in pregnancy: current concepts. Obstet Gynccol 1980; 55: 739-43.

3 Sims $C D$, Chamberlain $G V P$, de Swiet $M$. Lung function tests in bronchial asthma during and after pregnancy. $\mathrm{Br}$ J Obstet Gynecol 1976; 83: 434-7.

4 Gluck JC, Gluck, PA. The effects of pregnancy on asthma: A prospective study. Ann Allergy 1976; 37: 164-8.

5 Topilsky $M$, Levo $Y$, Spitzer SA, Lewinski U, Atsmon A. Status asthmaticus in pregnancy: A case report. Ann Allergy $1974 ; 32 ; 151-3$.

6 Gelber M. Sidi Gassner $S$ et al. Uncontrollable lifethreatening status asthmaticus - an indicator for termination of pregnancy by cesarean section. Respiration 1984; 46: 320-2.

7 Kingston HGG, Hirshmun CA. Perioperative management of the patient with asthma. Anesth Analg 1984; 63: 844-55.

8 Marx GF. Obstetric anesthesia in the presence of medical complications. Clin Obstet Gynecol 1974; 17: 177-8.

9 VanArsdel PP, Glennon HP. Drug therapy in the management of asthma. Ann Int Med 1977; 87: 68-74.

10 Turner EE, Greenberger PA, Patterson R. Management of the pregnant asthmatic patient. Ann Int Med 1980; 93: 905-18.

11 Greenberger PA, Patterson R. Management of asthma during pregnancy. N Engl J Med 1985; 312: 897-902.

12 Templeton A, Kelman $R$. Maternal blood-gases, $\left(\mathrm{PAO}_{2}-\right.$ $\mathrm{PaO}_{2}$ ), physiologic shunt and VD/VT in normal pregnancy. Br J Anacsth 1976; 48: 1001-4.

13 Awe RJ, Nicotra $M B$, Newsom $T D$, Viles $R$. Arterial oxygenation and alveolar-arterial gradients in term pregnancy. Obstet Gynecol 1979; 53: 182-6. 
14 Motoyama EK, Rivard G, Acheson F, Cook CD. The effect of changes in matemal $\mathrm{pH}$ and $\mathrm{pCO}_{2}$ on the $\mathrm{PO}_{2}$ of fetal lambs. Anesthesiology 1967; 28: 891

15 Levinson G, Shnider SM, deLarimier AA, Steffenson JL. Effects of maternal hyperventilation on uterine blood flow and fetal oxygenation and acid-base status. Anesthesiology 1974; 40: 340-7.

16 Gare DJ, Shime J, Paud WM, Hoskins M. Oxygen administration during labor. Am J Obstet Gynecol 1969; 105 954-61.

17 Novy MJ, Edwards MJ. Respiratory problems in pregnancy. Am J Obstet Gynecol 1967; 99: 1024-45.

18 Meschia G. Supply of oxygen to the fetus. J Reprod Med 1979; 23: 160-5.

19 Marx GF, Mateo $C V$. Effects of different oxygen concentrations during general anesthesia for elective caesarean section. Can Anaesth Soc J 1971; 18: 587-93.

20 Simonsson $B G$, Jacobs FM, Nadel JA. Role of autonomic nervous system and the cough reflex in the increased responsiveness of airways in patients with obstructive airways disease. J Clin Invest 1967; 46: 1812-8.

21 Triebe $G, J u l i c h H$. Neuere Aspekte zur Pharmakotherapie obstruktiver Atemwegserkrankungen mit besonderer Berucksichtigungdes Asthma bronchiale. Z Erkrank Atm-Org 1980; 155: 3-20.

22 Reed $C E$. Abnormal autonomic mechanisms in asthma. J Allergy Clin Immunol 1974; 53: 34-41.

23 Miller MM. Fish JE, Patterson R. Methacholine and physostigmine airway reactivity in asthmatic and nonasthmatic subjects. J Allergy Clin Immunol 1977; 60: 116-20.

24 Kaliner $M$, Shethamer J, Davis $P B$, Smith $L$, Venter $J C$. Autonomic nervous system abnormalities and allergy. Ann Int Med 1982; 96: 349-57.

25 Kitahara $L H$, Collins JG. Spinal action of narcotic analgesics. Anesthesiology, 1981; 54: 153-63.

26 Justins DM. Francis D, Houlton PG, Reynolds F. A controlled trial of cxtradural fentanyl in labour, Br J Anaesth 1982; 54: 409-14.

27 Skerman JH. Thompson BA, Goldstein MT, Jacobs MA, Gupta A, Blass NH. Combined continuous epidural fentanyl and bupivicaine in labor: A randomised study. Anesthesiology 1985; 63: A450.

\section{Résumé}

L'anesthésie régionale est une technique convenable pour traiter une parturiente asthmatique. Nous rapportons le cas d'une asthmatique en travail chè qui l'administration rapide d'une analgésie péridurale au bupivacaïne-fentanyl a été associée d̀ une amelioration de 'l'efficacité d'une thérapie médicale concourante pour bronchospasme. Avant de débuter le blocage péridural, on a employé de t'arropine par inhalation dans une tentative de réduire le tonus parasympathique des muscles lisses bronchiques. Une amélioration clinique soutenue. ne s'est produite qu'apres la sortie du foetus et du placenta. 